\title{
Growth, feeding and reproduction of the catfish Eremophilus mutisii (Pisces: Trichomycteridae), from artificial reservoirs in Colombia
}

\author{
Gabriel Pinilla ${ }^{1}$, Maritza Abril ${ }^{2}$ \& Esperanza González ${ }^{1}$ \\ 1 Laboratorio de Limnología, UJTL, Carrera 4 No.22-61, Módulo 5, Piso 8, Bogotá, Colombia; \\ gabriel.pinilla@utadeo.edu.co; olga.gonzales@utadeo.edu.co \\ 2 University of Southern Mississippi, Biological Sciences. PO Box 5018. Hattiesburg, MS 39406; \\ mabril@ocean.otr.usm.edu
}

Recibido 11-VII-2000. Corregido 02-II-2002. Aceptado 04-V-2005.

\begin{abstract}
The catfish, Eremophilus mutisii, was cultured under different densities in artificial rainfall reservoirs at Caldas, Boyacá, Colombia. At capture, the average total length of the animals was $10 \mathrm{~cm}$ and the weight ranged between 9 and $10 \mathrm{~g}$. These fish were in initial stages of sexual development. After a year in the reservoirs, they had increased in length and weight as follows (densities in parentheses): $5.22 \mathrm{~cm}$ and $27.23 \mathrm{~g}(0.5$ individuals $\left./ \mathrm{m}^{2}\right) ; 1.98 \mathrm{~cm}$ and $8.79 \mathrm{~g}\left(1\right.$ individual $\left./ \mathrm{m}^{2}\right)$, and $2.45 \mathrm{~cm}$ and $0.82 \mathrm{~g}\left(2\right.$ individuals $\left./ \mathrm{m}^{2}\right)$. They were at the early stages of sexual maturity, and their condition factor fluctuated between 0.61 and 0.96 . They preferably ingested insect larvae that were found in benthic and littoral communities of the reservoirs. The benthos was dominated by ephippia of Daphnia, lumbriculids, and chironomid larvae. The biomass of benthic organisms ranged between 0.1126 and $1.3847 \mathrm{~g} / \mathrm{m}^{2}$. In the littoral community aquatic insects were the most important component, especially the hemipterans. The biomass of the littoral fauna ranged between 0.14 and $4.05 \mathrm{~g} / \mathrm{m}^{2}$. Rev. Biol. Trop. 54(2): 589-597. Epub 2006 Jun 01.
\end{abstract}

Key words: Eremophilus mutisii, Trichomycteridae, growth observations, gut content, Colombia.

The catfish Eremophilus mutisii is an endemic species and the only catfish present in the Cundiboya highlands of Colombia. Both the catfish and the highlands have suffered considerable habitat disturbance. This fish represent an important source of vitamins and animal protein to supplement the diet of the rural population. The deterioration of natural populations of E. mutisii has been evident; in Fúquene Lagoon, for example, Mayorga (1992) not only observed a decrease in size but also the attainment of sexual maturity at small sizes. This suggests that the reproduction of individuals takes place at early stages, perhaps as a survival mechanism for facing adverse conditions (Mayorga 1992). The impairment of the catfish habitat is related to a decrease in quality and quantity of continental waters due to pollution problems, loss of ground cover in the headwaters of rivers and streams, the improper use of water resources, etc. In addition to these problems, overfishing, the improper use of fishing methods and the absence of specific regulations can be added. This impairs the implementation of an adequate management of the species.

Realizing the importance of E. mutisii, researchers have become interested in studying different aspects of its biology and ecology (Amaya 1975, Beltrán 1992, Mayorga 1992) and also the possibility of its cultivation (Del Castillo and Garzón 1985). The first attempt to culture E. mutisii in small land-based reservoirs was made in the microbasin of the stream La Playa in Caldas, Boyacá, in which a preliminary study was conducted over a 
one year period (Pinilla et al. 1998). From that investigation several observations have emerged, one of which suggested using these reservoirs (which principally function to store water for agricultural use) as places to culture the catfish. Some other studies have been conducted to attempted the culture of the species in cement reservoirs (Del Castillo and Garzón 1985, Rodríguez 1992). The current investigation was designed to determine whether culture density is a factor that affects the growth and gonadal development of individuals. The design included monitoring factors associated with the physiological well being of the fish and determining the feeding aspects of the species in this kind of aquatic ecosystem. No food supplement was added and it was assumed that the food supply offered by the reservoirs would be adequate for growth and development.

\section{MATERIALS AND METHODS}

Geographic area. The area of study corresponds to the high basin of the Suárez River, municipality of Caldas, Department of Boyacá, at $5^{\circ} 33^{\prime} 30^{\prime \prime} \mathrm{N}$ and $73^{\circ} 1^{\prime} 40^{\prime \prime} \mathrm{W}$. The municipality is located between 2550 and 3200 masl and the mean temperatures varies between 12 and $13^{\circ} \mathrm{C}$. The first rainy season is during April and May and the second is during September, October, and November; the annual mean precipitation ranges between 870 and $1000 \mathrm{~mm}$ (UJTL 1991).
Culture of fish. Native fishermen captured 1551 specimens of E. mutisii in the Fúquene Lagoon (May-June 1995). The specimens were weighed (precision $\pm 0.1 \mathrm{~g}$ ) and measured (precision $\pm 0.5 \mathrm{~cm})$. The number of individuals placed in each reservoir depended on the surface area of the reservoirs: two individuals per square meter were placed in reservoirs one and two, one individual per square meter in reservoirs three and four, and $1 / 2$ individual per square meter in reservoirs five and six (Table 1).

Samplings. The first samplings were done between 30 June and 1 July 1995; the second between the fourth and sixth of August; the third between 21 and 23 September; and the fourth between 15 and 16 February 1996. In each sampling physical-chemical analyses of the water were performed and samples of littoral and benthic organisms were taken. We could not recover any specimens of E. mutisii from the reservoirs with any of various methods we tried. As a consequence, two additional samplings were made between 27 and 29 March and between 15 and 18 June 1996, just to capture the catfish. The depth and transparency of each reservoir was estimated with a Secchi disk; also were taken surface temperature, bottom temperature, surface oxygen, bottom oxygen, conductivity, dissolved solids, calcium hardness, magnesium hardness, total hardness, alkalinity, silicates, iron, ammonium, nitrates, nitrites, ortophosphates, sulfates, and chlorine. Water samples were preserved to determine

TABLE 1

Starting data for the E. mutisii experiment

$\begin{array}{lcccccc} & \text { Reservoir 1 } & \text { Reservoir 2 } & \text { Reservoir 3 } & \text { Reservoir 4 } & \text { Reservoir 5 } & \text { Reservoir 6 } \\ \begin{array}{l}\text { Date of culture } \\ \begin{array}{l}\text { Density of culture } \\ \text { (individual } / \mathrm{m}^{2} \text { ) }\end{array}\end{array} & 2.2 & 2.19 & 1.1 & 1.09 & 0.3 & 0.6 \\ \begin{array}{l}\text { Number of cultured } \\ \text { fishes }\end{array} & 682 & 600 & 109 & 114 & 32 & \text { 3 June 1995 } \\ \text { Weight average (g) } & 9.7 & 10.1 & 8.9 & 9.5 & 9.6 & 14 \\ \begin{array}{l}\text { 27 May 1995 } \\ \text { Length average (cm) }\end{array} & 10.7 & 10.8 & 10.6 & 10.7 & 10.7 & 10.4\end{array}$


in the laboratory the total phosphorus and the biological oxygen demand (BOD) (APHA 1989). Littoral macroinvertebrates were collected using a one square meter net with $1 \mathrm{~mm}$ mesh. Superficial and submerged fauna of the littoral zone were collected with this net in areas where macrophytes were present; they were preserved with $10 \%$ formalin. Benthic community samples were taken in the center of each reservoir using an Eckman grab with an area of $0.19 \mathrm{~m}^{2}$. The sediment was passed through a $500 \mu \mathrm{m}$ sieve, organisms were collected in plastic bags, and they were preserved in $10 \%$ formalin. Aqueous $2.5 \%$ Rose Bengal was added to stain the organisms. Small traps were specially designed to capture catfish. They were made of $5 \mathrm{~cm}$ PVC tubes $40 \mathrm{~cm}$ long with a $1.6 \mathrm{~mm}$ mesh at one end and a cord to hold them on the other end. Also employed were fishing nets known in the area as "mochilos" which consisted of hoops with conical nets of $1 \mathrm{~cm}$ mesh and large wooden handles for maneuvering. Other fishing methods included use of $3 \times 10 \mathrm{~m}$ nets positioned in the bottoms of the reservoirs and baited with earth worms, perforated plastic jars containing macerated river crabs as bait, and modified mochilos that were located at the outlets of the reservoirs. For the last two field trips, some reservoirs were drained to collect the fish from the muddy bottom. The collected specimens were injected with $10 \%$ formalin and were preserved in vials with the same solution.

Laboratory. Analysis of total phosphorus and biological oxygen demand (BOD) were made according to APHA guidelines (1989). The littoral and benthic organisms were put in petri dishes and identified using specialized keys (Pennak 1978, Roldán 1989). All the individuals were weighed $(0.0001 \mathrm{~g}$ accuracy), and the data were converted to biomass per square meter for each reservoir. The preserved fish were weighed on a digital balance and measured with an ichthyometer graded in millimeters (total length and standard length). After that, a longitudinal incision was made in the ventral region of the fish and the complete digestive tract from the esophagus to the anus was removed. The digestive tract was measured with a millimeter ruler; the stomach was separated from the esophagus and gut and was preserved in $10 \%$ formaldehyde. The gonads were removed and observed under the stereo microscope to determine their stage of maturity, according to Amaya (1975). Ovaries and testicles as well as eviscerated fish were weighed on a digital balance. In order to evaluate feeding behavior, the stomachs were weighed full and empty and their state of fullness was recorded. A longitudinal incision was made to extract the stomach contents, which were analyzed under a stereo microscope to quantify and identify the different items using keys by Roldán (1989) and Pennak (1978).

Mathematical analysis. Averages of the physical-chemical parameters of the water and of the different biological parameters of the fish, the littoral macroinvertebrates, and the zoobenthos were calculated. Intestinal coefficiente and feeding indices (numeric, frequency and relative importance) were calculated with methods proposed by Prejs (1981) and the condition factor $\mathrm{K}$, sex proportion and the gonadosomatic index (GSI in percentage) were calculated according to Nikolsky (1963).

\section{RESULTS}

The physical environment of the small reservoirs. The surface temperatures were slightly high, with a range between 15 and $22.5^{\circ} \mathrm{C}\left(18^{\circ} \mathrm{C}\right.$ on average); on the bottom these values dropped to in $8^{\circ} \mathrm{C}$. The transparency of the water fluctuated between $15 \mathrm{~cm}$ and $1.1 \mathrm{~m}$. The $\mathrm{pH}$ of the reservoirs tended to neutrality with an average of 6.57 and a range of five to seven. Alkalinity registered 1.6 to $96.2 \mathrm{mg} / \mathrm{l}$ of $\mathrm{CaCO}_{3}$; reservoirs five and six were characterized by their low alkalinity. Conductivity oscillated between 41 and $263 \mu \mathrm{S} / \mathrm{cm}$. The highest conductivities were in reservoirs one and four and the lowest were in reservoirs five and six. Sulfates present in the reservoirs one 
through four ranged between 10 and $60 \mathrm{mg} / \mathrm{l}$ of $\mathrm{SO}_{4}$. The hardness was moderate, with exception of reservoirs five and six where was low. In summary, reservoirs one through four exhibited high mineralization, while reservoirs five and six exhibited low mineralization. Ammonia and nitrate levels were relatively high ( 0.32 to $1.52 \mathrm{mg} / \mathrm{l}$ and 0.2 to $2.0 \mathrm{mg} / \mathrm{l}$, respectively). Orthophosphate levels ranged between 0.009 and $2.063 \mathrm{mg} / \mathrm{l}$ and the total phosphorous (as P) ranged between 0.024 and $0.178 \mathrm{mg} / \mathrm{l}$. The presence of cattle can contribute, through excrement, to the enrichment of water. The BOD fluctuated between 16.50 and $73.20 \mathrm{mg} / \mathrm{IO}_{2}$.

Initial conditions of the cultured catfish. The quantities of cultured fish from each reservoir and their average measurements are shown in Table 1. The total length was just over $10 \mathrm{~cm}$ and the weights averaged between 9 and 10 g. These specimens cannot be considered fry, but diminutive adults because they have largely completed their morphological development. The analysis of a group of fish collected from the cultured populations show that the majority exhibited early stages of gonadal maturity (state I), some had gonads in intermediate states of development (state R), and only one showed an advanced state of maturation (state M). This fish had gonadal indices ranged between 5.83 and 15.52, comparable with those reported by Mayorga (1992) of 6.9 and 13.2. This index becomes higher (20 to 30 ) as the animal approaches the spawning period. These data show that the cultured fish were in early stages of sexual development. Gastrointestinal tract analysis of E. mutisii came from Fúquene Lagoon, confirmed the carnivorous habit of the species (Amaya 1975), since it contained mainly mollusks and annelids and some arthropods (Chironomus spp. larvae).

Biological aspects of the cultured catfish in small reservoirs. Three samples of fish collected from three of the reservoirs are described. Five catfish were collected from reservoir two ( 2 individuals $/ \mathrm{m}^{2}$ ), 40 catfish from reservoir four ( 1 individual $/ \mathrm{m}^{2}$ ), and three catfish from reservoir six $\left(0.5\right.$ individuals $\left./ \mathrm{m}^{2}\right)$, for which morphometric and biological data are presented in Table 2. Collecting catfish from the small reservoirs proved to be very difficult; therefore, our analysis offers a comparative view of the cultured fish and the ones collected at the end of the experiment, as well as a descriptive view among the treatments (densities of culture). The average sizes and weights, both initial (at the moment of the culture) and final (one year later), are presented in Table 3. The greater results in growth and weight were recorded in reservoir six, where the average increase in length was $5.22 \mathrm{~cm}$ and in weight was $27.34 \mathrm{~g}$, but it is necessary to remember that this results belong only to three fishes; the lower population densities $\left(0.5\right.$ individuals $\left./ \mathrm{m}^{2}\right)$ were cultured in this reservoir. In reservoirs with higher population densities ( 2 and 1 individual $/ \mathrm{m}^{2}$, Table 1$)$, the growth and increase in weight were only $2.45 \mathrm{~cm}$ and $0.82 \mathrm{~g}$ for the reservoir two and $1.98 \mathrm{~cm}$ and $8.79 \mathrm{~g}$ for reservoir four. At the reservoir four the growth

TABLE 2

Average of some morphometric and biological variables of $\mathrm{E}$. mutisii after one year in the small reservoirs

$\begin{array}{cccc}\text { Lake } & \begin{array}{c}\text { Sex } \\ \text { Proportions }\end{array} & \begin{array}{c}\text { Total } \\ \text { length }\end{array} & \begin{array}{c}\text { Gonadal } \\ \text { stage }\end{array} \\ 2 & 3+: 2- & 11.56 & 4 \mathrm{I}: 1 \mathrm{R} \\ 4 & 3+: 1- & 12.76 & 28 \mathrm{R}: 12 \mathrm{M} \\ 6 & 2+: 1- & 15.43 & 3 \mathrm{M}\end{array}$

I: immature; R: in development; M: mature; + males; - females

TABLE 3

Average of the initial lengths and weights of $\mathrm{E}$. mutisii after one year in the small reservoirs

\begin{tabular}{ccccc}
\multirow{2}{*}{ Reservoir } & \multicolumn{2}{c}{ Initial fishes } & \multicolumn{2}{c}{ Cultured fishes } \\
& Length & Weight & Length & Weight \\
2 & 9.11 & 8.72 & 11.56 & 9.54 \\
4 & 10.78 & 9.76 & 12.76 & 18.55 \\
6 & 10.21 & 7.89 & 15.43 & 35.23
\end{tabular}


of the fish was less than that in the higher population density (reservoir two), but at the same time, they exhibited a greater increase in weight. Note, however, that specimens collected from reservoirs two and six were scarce and our results may be influenced by the size of the sample; for this reason, statistical analyses were not made.

The smallest $\mathrm{K}$ value took place in the reservoir two ( 0.61 average); for reservoir four the average value was 0.845 , and the highest value occurred at reservoir six (0.96 average). As the culture density decreased, the condition factor increased but in all cases $\mathrm{K}$ values indicated well-fed fish. Of 48 individuals captured in the three reservoirs, 13 were females (F) and 35 were males $(\mathrm{M})$ making the proportion of catfish $3.7 \mathrm{M}: 1 \mathrm{~F}$. The states of maturity for E. mutisii cultured in small reservoirs are shown in Table 2: fifteen fish were found in a mature state (state three or M, according to Amaya 1975), 29 in a developing state (state two or R), and four in an immature state (state one or I). The fish, prior to the study, were already in an initial state of gonadal development. The GSI fluctuated between 3.3 and 7\% on average and it is low if compared with the GSI of the sample of fish taken before being cultured, which averaged $8.68 \%$. These data make suggest that, after the experiment, the animals were somewhat mature but not completely sexual developed.
The intestinal coefficient (ranged between 0.77 and 1.03 ) reflects the carnivorous habits of the E. mutisii, since values equal to or less than one are characteristic of zoophagous species (Chiriví and León 1982). The E. mutisii indices of feeding in the reservoirs four and six show a carnivorous habit too, since the stomach items were mainly insect larvae (Table 4). The numeric and frequency indices for the items found, as well as the index of relative importance, show that chironomids were the principal food for the three fishes captured in the reservoir six; hemipterans, odonatans, and lumbriculids were found as occasional food. The most important item for the 40 fishes captured in reservoir four was the odonatans with chironomids as secondary food. Virtually all of the stomachs analyzed had undigested contents at the time of capture; this suggests that $E$. mutisii feed not only during the day but also at night, since the captures made in the afternoon showed that the stomach contents were not digested.

\section{Alimentary supply of reservoirs.} Seventeen morphospecies of littoral macroinvertebrates were identified; these organisms were mollusks and arthropods. Hemipterans were the most abundant group. Species of Buenoa were present in all the reservoirs. In abundance it was followed by other hemipterans such as Centrocorisa spp., Tenegobia spp., and Notonecta spp. These species belong to the

TABLE 4

E. mutisii feeding indexes for reservoirs four and six

\begin{tabular}{|c|c|c|c|c|c|c|}
\hline \multirow[b]{2}{*}{ Feeding item } & \multicolumn{2}{|c|}{ Numeric Index (\%) } & \multicolumn{2}{|c|}{ Frequency index $(\%)$} & \multicolumn{2}{|c|}{ Index of relative importance } \\
\hline & $\begin{array}{c}\text { Reservoir } \\
4\end{array}$ & $\begin{array}{c}\text { Reservoir } \\
6\end{array}$ & $\begin{array}{c}\text { Reservoir } \\
4\end{array}$ & $\begin{array}{c}\text { Reservoir } \\
6\end{array}$ & $\begin{array}{c}\text { Reservoir } \\
4\end{array}$ & $\begin{array}{c}\text { Reservoir } \\
6\end{array}$ \\
\hline Hemipterans & 0.92 & 2.25 & 7.5 & 100 & 0.07 & 2.5 \\
\hline Chironomids & 13.36 & 93.80 & 52.5 & 100 & 7.01 & 93.8 \\
\hline Odonats & 79.50 & 1.69 & 92.5 & 66.6 & 73.54 & 1.1 \\
\hline Lumbriculids & 0.23 & 2.26 & 2.5 & 100 & 0.06 & 2.3 \\
\hline Gordians & 0.92 & 0 & 2.5 & 0 & 0.02 & 0 \\
\hline Coleopterans & 5.07 & 0 & 12.5 & 0 & 0.63 & 0 \\
\hline
\end{tabular}


families Corixidae and Notonectidae that are characterized as being excellent swimmers (Pennak 1978). The coleopterans were less abundant; they are typical from riverine areas and swim freely or are located in the vegetation. Species of Androgyrus (Gyrinidae) were the most abundant. Other groups that contributed low proportions to the total of collected organisms were odonats, dipterans, and mollusks from the genus Lymnaea. The biomass of the littoral organisms from all the reservoirs ranged between $0.1 \mathrm{~g} / \mathrm{m}^{2}$ and $4.0 \mathrm{~g} / \mathrm{m}^{2}$. E. mutisii apparently prefer chironomid and odonat larvae.

The major groups of zoobenthic community were arthropods, nematodes, and annelids. The arthropods included Chironomus spp. and Pentaneura spp. (Insecta), Daphnia spp. (represented by its cyst form known as ephippium; Cladocera), and Cypris spp. (Ostracoda). The nematodes belonged to the species Nygolaimus and the annelids to a morphospecies of the family Lumbriculidae. The most numerous species was Daphnia in its ephippium stage. The ephippium of this primary consumer corresponds to resistant structures produced by the organism when it faces stress situations. High numbers were found on the sediments of the reservoirs, which indicate that adverse conditions for this species exist in the reservoirs. The oligochaete family was the second most abundant, followed by chironomid larvae, especially in reservoirs five and six. These dipterans, as well as the littoral odonats, were the preferred preys for E. mutisii. The nematode Nygolaimus sp. was found only in reservoirs one and two and, although abundant, its frequency was irregular. The biomass of the benthic community ranged between 0.1 and $1.3 \mathrm{~g} / \mathrm{m}^{2}$.

\section{DISCUSSION}

The majority of the reservoirs showed hypoxic or anoxic conditions in the bottom waters. Arteaga (1999) and Pinilla and Guillot (1999) demonstrated the formation of thermoclines and oxiclines in these aquatic environments, in spite of their scant depths ( 2 to $3 \mathrm{~m}$ ). The low transparency is associated with the composition of the ground and depends on its time of construction; in general, the most recently constructed reservoirs are more turbid because they have more clay along their bottoms. Alkalinity for some of the reservoirs was high, even though it was within the values reported for neotropical waters (less than $100 \mathrm{mg} / \mathrm{l}$, Esteves 1988, Roldán 1992). Conductivity was high compared to ranges reported for some neotropical systems such as the Amazonian black rivers $(10 \mu \mathrm{S} / \mathrm{cm}$, Payne 1986) or the high Andean environments (3.2 to $35.0 \mu \mathrm{S} / \mathrm{cm}$, Gaviria 1993). Nitrite was undetectable indicating normal oxidative processes from the ammonia to nitrate were occurring in these reservoirs; low nitrite suggests an stable aquatic ecosystem (Margalef 1983). Orthophosphate was high compared with the ranges for Amazonian waters and high mountain regions with 0.001 to $0.020 \mathrm{mg} / 1$ (Roldán 1992) and follow, just as nitrogen, the fertilization processes of agrochemicals in the zones surrounding the reservoirs. The $\mathrm{pH}$ and calcium magnesium values are found within the expected values for the Andean regional waters (Roldán 1992); all the physical-chemical parameters agree with the investigations carried out in the region by Fernández and Pinilla (1996), Páramo and Pinilla (1996), Pinilla et al. (1998), Arteaga (1999) and Pinilla and Guillot (1999). E. mutisii tolerates the conditions of these small reservoirs and it does not seem to alter the physical-chemical characteristics of the water.

The fish condition factors in the reservoirs are similar to those reported by Mayorga (1992) for the Fúquene Lagoon. Amaya (1975) found excessive feeding among the catfish with monthly variations. However, is necessary to keep in mind that $\mathrm{K}$ formula is based in spherical fishes, while E. mutisii trends to be elongated. This is the reason that a high condition factor in this fish could be influenced by length with respect to weight in comparison to other species. The sizes and states of maturity reported here are similar to those found by Mayorga 
(1992) for E. mutisii of Fúquene Lagoon. Amaya (1975), however, found maturing specimens larger than $17.7 \mathrm{~cm}$ in length and mature fish longer than $20.5 \mathrm{~cm}$. According to some authors (Amaya 1975, Cala and Sarmiento 1982, Cala 1986, Beltrán 1992), E. mutisii first reach sexual maturity between 14 and $20 \mathrm{~cm}$ of total length. Mayorga (1992) found that this size is reduced to $9 \mathrm{~cm}$ for fish in the Fúquene Lagoon, the place from which the cultured fish in the reservoirs were collected. Apparently the individuals coming from the Fúquene Lagoon tend to grow faster than the ones coming from other places. In relation with the sex distribution, in Fúquene Lagoon the proportion reported by Mayorga (1992) was $1.26 \mathrm{M}: 1 \mathrm{~F}$ and, in the Neusa Dam, Beltrán (1992) found 3M:1F. Only Amaya (1975) reported a proportion of 1:1 for the Tota Lagoon; our data are looked like those of the first authors, although they can be affected by the small size sample.

The development of the gonads after a year of experimentation indicates that the fish were maturing sexually but not completely. Even though the majority of the fish at the end of the experiment appear to reach some grade of maturity, E. mutisii populations confined in the small reservoirs were unable to spawn. According to Beltrán (1992), for some dams of the Cundiboyacense highlands, the water level must rise in order for the fish to spawn. Our data suggest that water in the rainfall reservoirs does not reach sufficient levels for $E$. mutisii to spawn. Apparently E. mutisii is not exposed in the small reservoirs to the environmental mechanism that triggers maturation of its gonads, or the food source was insufficient for normal reproductive development and, on the contrary, was channeled into an increase of the body weight and into the maintenance of other vital processes. Fries would be needed to repopulate reservoirs periodically or to develop hormonal methods for obtains the reproduction of $E$. mutisii under these conditions.

The stomach contents observed for the catfish in small reservoirs have some differences with those found by Mayorga (1992) in the Fúquene Lagoon, which can be attributed to the fact that in the small reservoirs the composition of the benthic and littoral communities is different. The maturity and antiquity of the lagoonar system of the Fúquene, in contrast to the immaturity and recent creation of the rainfall reservoirs, may be responsible for these differences. The reservoirs had a small number of benthic and littoral macroinvertebrate species with reservoir one showing the greatest variety, possibly for being the oldest. The biomass of the littoral and especially of the benthic organisms is relatively low. These data show the ecological simplicity of the small aquatic ecosystems studied. Nevertheless, the found taxonomic groups in the content of stomach of catfish, such as larvae of insect and oligochaetes, reflect the utilization of reservoirs food provision.

Increases in length and weight of the catfish did not achieve commercial size in reservoirs one through four, while catfish did achieve commercial size in the lower population density $\left(0.5\right.$ individuals $\left./ \mathrm{m}^{2}\right)$ of reservoirs five and six. A higher population density would lead to greater competition for food resources; our data suggest that there isn't abundant availability of food in the reservoirs. Moreover, E. mutisii exhibits certain selectivity for particular species; this preference detracts from the amount of food available for the catfish and may explain the increase of interspecific competition for food as the population density of the culture is increased. These observations, suggest the necessity of establishing a supplementary diet to improve the growth and fattening of the fish under high densities. Apparently competition for space is other important phenomenon that influences the development of E. mutisii in this type of reservoir. It is known that this species is very territorial and that it requires refugees to avoid the competition for space (Del Castillo and Garzón 1985). In the artificial reservoirs these natural refugees are scarce.

The catfish E. mutisii are hard to capture in the small, artificial reservoirs. Benthic fishes like E. mutisii are located in the "deep or benthic zone, above or within the substrate" 
(Lagler 1975). Its benthic habit apparently precluded the periodic capture of specimens raised in the small reservoirs, even though several different techniques were used to recapture them. The traps utilized had been used successfully in previous research (Pinilla et al. 1998), but in the present investigation they were not effective. The other technique (mochilo) was the more efficient tool for recapturing fish in the investigation developed by Mayorga (1992); however Mayorga used the mochilos at night and under floating vegetation. In the small reservoirs fishing occurred during the day and there is no surface vegetation except that which is rooted in the littoral zone. Other methods used (nets baited with earthworms, perforated containers with freshwater crabs as bait, and nets at the outlets of the reservoirs) were not effective. The only way to recover the fish was to drain the reservoirs. In the future other different methods for capturing the catfish should be investigated. One alternative could be an annual drying of the reservoirs to collect the fish, programming this activity to the beginning of the rainy season so the reservoirs would recover rapidly.

\section{ACKNOWLEDGMENTS}

This study was made possible by financial support from the FEN Colombia Foundation and the Jorge Tadeo Lozano University. The authors thank Abdón Cortés Lombana (Scientific Research and Environmental Studies Center of the University), for his enthusiasm and scientifical advise; Daniel Gutiérrez, inestimable collaborator on field trips; and especially to the families from the Espalda and Cubo villages, who gave us their generous assistance and let us use their reservoirs as experimentation places. We thank Kenneth J. Curry for his critical review of the manuscript.

\section{RESUMEN}

El "capitán de la sabana", Eremophilus mutisii (Humboldt, 1805), fue cultivado en diferentes densidades en pequeños lagos artificiales localizados en Caldas, Boyacá, Colombia. Al inicio, el promedio de la longitud corporal fue $10 \mathrm{~cm}$ y el peso osciló entre 9 y 10 gr. Los peces se encontraban en estados iniciales de desarrollo sexual. Luego de un año de experimentación, los peces cultivados a una densidad de $0.5 \mathrm{ind} / \mathrm{m}^{2}$ incrementaron $5.22 \mathrm{~cm}$ en longitud y $27.23 \mathrm{gr}$ en promedio $\left(1 \mathrm{ind} / \mathrm{m}^{2}\right.$ : $1.98 \mathrm{~cm}$ y $8.79 \mathrm{gr} ; 2 \mathrm{ind} / \mathrm{m}^{2}: 2.45 \mathrm{~cm}$ y $\left.0.82 \mathrm{gr}\right)$. Los peces se encontraban iniciando su madurez sexual, y su factor de condición fluctuó entre 0.61 y 0.96 y consumían principalmente larvas de insectos. El bentos estaba dominado por efipios de Daphnia, lumbricúlidos y larvas de quironómidos. La biomasa de organismos benticos osciló entre 0.1126 y $1.3847 \mathrm{gr} / \mathrm{m}^{2}$. En la comunidad litoral, los insectos acuáticos fueron los componentes mas importantes, especialmente los hemípteros. La biomasa de la fauna litoral osciló entre 0.14 y $4.05 \mathrm{gr} / \mathrm{m}^{2}$.

\section{REFERENCES}

Amaya, R. 1975. Contribución al estudio biológico del capitán de la sabana Eremophilus mutisii Humboldt, 1805 en el lago de Tota. Tesis Biología Marina, Universidad Jorge Tadeo Lozano, Bogotá, Colombia. 221 p. anexos.

American Public Health Asociation (APHA). 1989. Standard methods for examination of water and wastewater. Amer. Pub.Heal.Asociation, Washington, D.C. 1536 p.

Arteaga, M.E. 1999. Aspectos biotipológicos y estructurales de la comunidad de macrófitas en pequeños lagos artificiales en el altiplano cundiboyacense. GEOTROPICA (Bogotá). 4: 5-13.

Beltrán, S. 1992. Estado actual de las poblaciones de Eremophilus mutisii (Humboldt, 1805) (Pisces: Trichomycteridae) en algunos cuerpos de agua del Altiplano Cundiboyacense. Centro de Investigaciones Científicas, Universidad Jorge Tadeo Lozano, Bogotá. 161 p. (typed copy).

Cala, P. 1986. Cambios histomorfológicos en los testes del Capitán, Eremophilus mutisii (Trichomycteridae, Siluriformes), durante el ciclo reproductivo anual en el sistema del Río Bogotá en Colombia. Caldasia (Bogotá). 14: 659-678.

Cala, P. \& N. Sarmiento. 1982. Cambios histomorfológicos en el ovario del pez capitán, Eremophilus mutisii Humboldt, 1805 (Pisces: Trichomycteridae), durante el ciclo reproductivo anual, en la laguna del Muña, sistema del Río Bogotá. Colombia. Act. Biol. Col. (Bogotá). 1: 9-30.

Chiriví, H. \& C. León. 1982. Descripción de una nueva especie troglobia del género Trichomycterus 
(Osteichthyes, Siluriformes, Trichomycteridae) de la Cordillera Oriental de Colombia. Tesis Biología, Universidad Nacional, Bogotá, Colombia. 170 p.

Del Castillo, B. \& B. Garzón. 1985. Observaciones sobre la biología del capitán Eremophilus mutisii (Humbolt, $1805)$ en condiciones de laboratorio con fines piscícolas. Tesis Biología Marina, Universidad Jorge Tadeo Lozano, Bogotá, Colombia. 180 p.

Esteves, F. 1988. Fundamentos de limnología. Interciencia, Rio de Janeiro, Brazil. 575 p.

Fernández, N.J. \& G. Pinilla. 1996. Análisis multivariados aplicados al estudio de la estructura y función de la comunidad bentónica de pequeños lagos artificiales en la microcuenca de la quebrada La Playa, Caldas, Boyacá. Memorias del Seminario-Taller de Limnología "Investigaciones Limnológicas Recientes en Ecosistemas Acuáticos Tropicales". Universidad Jorge Tadeo Lozano, Colciencias, Bogotá. p. 73-100.

Gaviria, S. 1993. Aspectos limnológicos de las lagunas de Chingaza, p. 189-205. In G. Andrade (ed.). "Carpanta". Ecología y conservación de un ecosistema altoandino. Fundación Natura -The Nature Conservancy- Empresa de Acueducto y Alcantarillado de Bogotá (E.A.A.B.), Bogotá.

Lagler, K.F. 1975. Freshwater fishery biology. Brown, Dubuque, Iowa. 421 p.

Margalef, R. 1983. Limnología. Omega, Barcelona. 1111 p.

Mayorga, M. 1992. Biología reproductiva y alimentación de las poblaciones de capitán de la sabana Eremophilus mutisii, Humboldt 1805, (Pisces: Trichomycteridae) en la laguna de Fúquene. Tesis Biología Marina, Universidad Jorge Tadeo Lozano, Bogotá, Colombia. 86 p., anexos.

Nikolsky, G. 1963. The ecology of fishes. London. 352 p.

Páramo, R. \& G. Pinilla. 1996. Estructura de la comunidad planctónica de pequeños lagos artificiales en la microcuenca de la quebrada La Playa. Memorias del Seminario-Taller de Limnología "Investigaciones Limnológicas Recientes en Ecosistemas Acuáticos
Tropicales". Universidad Jorge Tadeo Lozano, Colciencias, Bogotá, p. 37-72.

Payne, A.I. 1986. The ecology of tropical lakes and rivers. Wiley, New York. 301 p.

Pennak, R.W. 1978. Freshwater invertebrates of the United States. Wiley, New York. 803 p.

Pinilla, G., N.R. Anzola, N.J. Fernández \& R. Páramo. 1998. Ecología de pequeños lagos artificiales en la microcuenca de la quebrada La Playa (CaldasBoyacá). GEOTROPICA (Bogotá). 3: 5-20.

Pinilla, G.A. \& G. Guillot. 1999. Patrones de distribución del fitoplancton en reservorios de aguas lluvias en un altiplano de los Andes colombianos. GEOTROPICA (Bogotá). 4: 39-63.

Prejs, A. 1981. Métodos para el estudio de los alimentos y las relaciones tróficas de los peces. Universidad Central de Venezuela, Caracas. 129 p.

Roback, S. 1974. Insects (Arthropoda:Insecta), p. 313-376. In C. Hart \& S. Fuller (eds.). Pollutions ecology of freshwater invertebrates. New York.

Rodríguez, A. 1992. Informe de las observaciones obtenidas sobre el comportamiento del capitán de la sabana, Eremophilus mutisii, en estanques de cultivo experimental en la estación piscícola del Neusa. Diciembre 1991 - Mayo 1992. Corporación Autónoma Regional de las Cuencas de los Ríos Bogotá, Ubaté y Suárez (CAR). Bogotá, 106 p. (typed copy).

Roldán, G. 1989. Guía para el estudio de los macroinvertebrados acuáticos del departamento de Antioquia. Fondo FEN Colombia - Colciencias - Universidad de Antioquia, Bogotá. 217 p.

Roldán, G. 1992. Fundamentos de limnología neotropical. Universidad de Antioquia, Medellín, Colombia. 529 p.

Universidad Jorge Tadeo Lozano (UJTL). 1991. Plan de ordenamiento y manejo ambiental de la microcuenca de la quebrada La Playa, Municipio de Caldas, Boyacá. Centro de Investigaciones Científicas, Bogotá. 339 p. (typed copy). 
